\title{
Examining the Skill in Writing Descriptive Text Among Indonesian Learners of English: The Effects of Task-Based Language Teaching (TBLT)
}

\author{
Kaharuddin \\ Faculty of Education and Teacher Training, Universitas Islam Negeri (UIN) Alauddin, Makassar, Indonesia \\ Mardiana \\ Faculty of Education and Teacher Training, Universitas Islam Negeri (UIN) Alauddin, Makassar, Indonesia
}

Djuwairiah Ahmad

Faculty of Education and Teacher Training, Universitas Islam Negeri (UIN) Alauddin, Makassar, Indonesia

\author{
Al Amini Indah Sari \\ Faculty of Education and Teacher Training, Universitas Islam Negeri (UIN) Alauddin, Makassar, Indonesia
}

\begin{abstract}
This study aims to examine the learners' skills in writing English descriptive text by employing The Explanatory-Sequential (QUAN-QUAL) research method. The data collection instruments were Writing Tests and Interview. The written tests were given in the form of pre and post-test to reveal the effect of Task-Based Language Teaching (TBLT) on improving the learners' English writing skills. Interviews were held to confirm factors affecting the students' skills in writing English descriptive texts. 27 learners of MA Madani Alauddin Pao-Pao, Gowa were purposively selected to participate in this study. The results reveal two things namely: The first, there is a statistically significant difference between mean scores of the experimental group (64.85) and the control group (55.03) in the test result after the treatment (post-test). The value according to Student's t-test confirms it: $t=5,846 ; p<0,001$. This result supports the effectiveness of employing Task-Based Language Teaching (TBLT) as a method in teaching English writing skills. The second, the interviews indicate that there are 5 determinants affecting the learners' skills in writing English descriptive texts, i.e. Learners' Interest, Teacher's Strategy, Teacher's Media, Classroom Environment, and Learners' Learning Strategy. Our results revealed that using TBLT has led to significant increases in the students' skill in writing descriptive texts. We believe, our findings could have a profound impact on the way English writing is taught around the world. Therefore, English language teachers should provide more opportunities to learn this method to enable them apply it in their English pedagogy.
\end{abstract}

Index Terms - task-based language teaching, English writing skills, writing descriptive text, Indonesian learners of English

\section{INTRODUCTION}

In the education system of Indonesia, English is the only foreign language learnt as a compulsory subject from secondary level e.g. Junior and senior high schools, to tertiary level of education e.g. colleges and universities (Kaharuddin, A. 2019). When English is learnt as a compulsory subject, students are required to learn at least for necessary skills i.e. speaking, listening, reading as well as writing skill. From the perspective of language pedagogy, the four skills may be classified into two major categories of skills namely receptive skills and productive skills (Kaharuddin, N. 2014). Receptive skills refer to language skills that are used to receive messages in social interactions such as listening and reading skill. On the other hand, productive skills refer to language skills that are used to produce messages in communications such as speaking and writing skills (Hasyim, M., Kuswarini, P., \& Kaharuddin. 2020). However, the primary focus of this paper is on writing skill. Many Indonesian learners of English begin learning how to communicate their ideas using written form in English when interacting with others at schools. As for the learners, writing skill is often considered to be more complicated than that of other language skills which makes them occasionally fail to communicate effectively in written form. This fact occurs because written form of communication requires a well-structured way of presenting abstract ideas. The well-structured way in writing English can be achieved when the learners have at least four types of knowledge namely, knowledge of content, knowledge of linguistic, knowledge of organization, and knowledge of style. The effectiveness of written form of communication is much determined by how good the learners' knowledge of the four types of knowledge is. However, many Indonesian 
learners of English have limited knowledge of the four knowledge categories which consequently makes English writing skill difficult to master (Kaharuddin, K., \& Rahmadana, A. 2020).

The fact is in line with the findings of some studies on writing which also indicate that English writing skill is generally considered as one of the most difficult English skills for many learners of English, it is due to the learners' limited knowledge of writing (Braine, G., \& Yorozu, M. 1998, Johnstone, Ashbaugh \& Warfield, 2002, Javed, M., Juan, W. X., \& Nazli, S. 2013, Kaharuddin, A. 2018). The limited knowledge of English writing is characterized by an inability to apply correct spelling, punctuation, grammar, diction, thesis statements, topic sentences and cohesive links within a paragraph, and global organization of texts (Kellogg, R. T., \& Raulerson, B. A. 2007). This issue is common to many learners of English, especially those who learn English in senior high schools. In senior high schools, writing skill is available in the syllabus since it is considered as an important skill for the learners' success in learning English. The writing skill extremely enables the learners to do three things i.e. to enrich English vocabulary when writing a lot, to acquire the mastery of English grammatical structure, and to help the development of other English skills such as reading, listening, as well as speaking (Bahar, A. K., \& Latif, I. 2019, Kaharuddin., \& Hasyim, M. 2020). In this regard, the learners are taught English writing skill by giving them lessons on how to write types of texts in English (procedure, descriptive, recount, and narrative texts), in which the learners' progress in their English writing skill is evaluated from their ability to write the types of texts in English well. Hence, this study closely investigates senior high school students who learn English at Madani Senior High School by giving special attention to descriptive texts.

The K-13 English syllabus of the high school clearly states that after learning lessons on writing descriptive texts, the students are able to master the art of writing descriptive texts which are characterized by their ability to construct simple descriptive texts about people and tourist destinations. However, this objective is not successfully achieved yet by the learners of English in schools. The result of preliminary study indicated three things i.e. the first, the students have restricted vocabulary which makes them difficult to select appropriate vocabulary when describing a thing (Andi, K., \& Arafah, B. 2017, Kaharuddin, Ahmad, D, Mardiana, Rusni 2020). The second, the students also acquire limited knowledge of English grammar that makes the improperly construct their sentences (Bahar, K. 2013). The third, they often complain about having limited knowledge of organizing ideas when writing which makes them feel writing as a daunting task (Kaharuddin, A., \& Latif, I. 2017). The facts have resulted in making the students lose interest in English lessons. Therefore, it stands to reason for saying that writing descriptive texts is a challenging task because it requires the students to exploit their potential in language writing by writing their ideas coherently and cohesively (Kaharuddin, Hikmawati, Arafah, B. 2019). Writing coherently and cohesively in English is a result of thinking and writing skill which are not naturally acquired, but must be intentionally learnt. For the reason, this study used task-based language teaching (TBLT) in the writing instructions as a special effort to encourage the students to learn and to increase their potential in writing English.

\section{LITERATURE REVIEW}

\section{A. Descriptive Text in Secondary School Context}

Writing is one of four important skills to master when learning English as a foreign language. The mastery of writing skill will help the learners to develop their English language acquisition for other skills since they directly practice their English vocabulary, grammar, ability to organize ideas in meaningful ways for the sake of communicating their idea effectively (Bello 1997). In other words, writing skill is not only a communication system that the students can use to share their ideas, but also a prerequisite to master the other language skills (Bahar, A. K. 2014). The skill in writing requires cohesive ability (e.g. the ability to use proper word selection, punctuation, spelling, and correct grammar) and coherent ability (e.g. ability to organize ideas properly, ability to arrange paragraphs in a good text structure, and ability to use proper text type). Those things are not naturally acquired, but can be learnt, practiced, as well as mastered by the learners (Arafah, B., \& Kaharuddin, 2019). Nunan (2003) specifically mentions that writing is both a physical and a mental act. Writing as a physical act refers to using required language to transfer messages in written texts such as vocabulary, spelling, punctuation, and grammar. On the other hand, writing as a mental act refers using ideas in mind, thinking around how to express them, and organizing them into explanations and paragraphs that will be clear to readers

Any types of written texts need both cohesive and coherent ability, including descriptive texts. A descriptive text is a piece of writing that indicates a description of characteristics of a thing such as a person or a place. This type of writing mainly uses senses that it specifically tells how something looks, feels, smells, tastes, and or sounds (Wesley, A., Oshima, A., \& Hogue, A. 1996). It is produced by using particular generic structures (i.e. identification: introducing the subject as the major topic; description of features: describing the characteristic features of the subject) and language features (i.e. using a particular noun as the major topic, using detailed group of nouns give detailed information on the subject, using a variety of adjectives, using relating verbs to connect information regarding the subject coherently, using various thinking and feeling verbs to convey the writer's personal view about the subject, using action verbs to illustrate the subject's behavior, using adverbials to give detailed information concerning the subject's behavior; and using similes, metaphors and other types of figurative expressions.

In the context of secondary level of Education, some studies on descriptive texts have been conducted (Siahaan, J. 2013, Masitoh, S., \& Suprijadi, D. 2015, Husna, L. 2017, Potradinata, S. L. A. 2018, Yoandita, P. E. 2019, Apriliana, R., 
Candra, M., \& Subroto, G. 2020). The results of the studies indicate that students find it difficult to write the descriptive texts, not only because they have limited knowledge of writing, but also because they are not familiar to the distinctive features of a descriptive text. Therefore, this study has attempted to apply Task Based Language Teaching (TBLT) as a method to cope with the students' difficulties in writing English descriptive texts. This study suggests English teachers to give special attention not only to teaching linguistic knowledge and cognitive knowledge of writing skill, but also to teaching the distinctive features of the descriptive texts along with their examples and practices that the learners can achieve the objective of learning English skill as stated in the K-13 English syllabus.

\section{B. Task-Based Language Teaching (TBLT)}

For the past 40 years, Task-based language teaching (TBLT) has been attracting the attention of many English language teachers all over the world. Some of them categorize it as an approach (Richards 2005), but some recognize it as a method 'the branch of Communicative Language Teaching' (Hashemi et al. 2012). Apart from the different perceptions of TBLT among English language teachers, something mutually accepted that the essence of TBLT is communicative tasks which are characterized by connectedness to real-world (Michael, H. 1985), social interaction goal (Candlin, 1987), primacy of meaning (Ellis, 2003), and non-linguistic achievement (Samuda \& Bygate, 2008). In other words, TBLT contains the use of authentic language and gets students to do meaningful activities by using the target language. Lessons presented using TBLT will focus more on developing the students' language fluency and confidence in using English, rather than on accuracy of grammar.

According to Hashemi et al. (2012), TBLT has 3 principle phrases in common which reflect the chronology of a taskbased lesson. They are Pre-task, During-Task, and Post-Task. The Pre-task phase is aimed at preparing the students to perform the task in ways that will promote acquisition. Hence, it is very important to present a task in a way that motivates the learners. Next, the During-task phase refers to the methodological option available to the teachers. The during-task phase consists of two things. The first, there are various options related to how the task needs to be undertaken that can be taken before the actual performance of the task and should be planned by the teacher. This is called as "task performance options". The second, there are several "process options" that involve the teacher and students in a decision making about how to perform the task as it is being completed. Finally, the Post-task phase is carried out to achieve three major pedagogic goals namely; to give students an opportunity to repeat a performance of the task, to encourage reflection on how the task was performed, and to encourage students' attention to some problematic language forms when performing the task.

For many years, some studies have been conducted to examine the advantages of applying a TBLT in the area of English language pedagogy. Jeon, I. J., \& Hahn, J. W. (2006) carried out a study on EFL teachers' perceptions of the use of task-based language teaching in Korean secondary schools and found that TBLT has a dramatic, positive impact on the students' English language development because TBLT provides learners with natural sources of meaningful material, ideal situations for communicative activity, and supportive feedback allowing for much greater opportunities for language use. Respectively, Dailey, A. (2009) conducted a study on the implementation of task-based language teaching in Korean classrooms and found that TBLT has its valuable points and is an exciting, and interactive method to improve the students' communicative competence. In addition, Liu, Y., Mishan, F., \& Chambers, A. (2018) also did a study on EFL teachers' perceptions after applying task-based language teaching in higher education in China and indicated that the majority of the Chinese EFL teachers appeared to hold positive views on TBLT and regarded that TBLT gave various advantages which help them to create more communicative speaking environments in their contexts Considering the positive reports of the studies on TBLT, this recent study makes effort to examine the advantages of applying TBLT in an experimental study which not only specially shows the effectiveness of TBLT on the students' development in writing skill, but also explains the reasons or the contributing factors behind the students' achievement.

\section{Methodology}

This study used a Mixed Method which involved the collection, analysis, and "mixing" of quantitative and qualitative research designs to answer the two research questions of this study (Hasjim, M., Arafah, B., Kaharuddin, S. V., \& Genisa, R. A. A. 2020), namely; 1). Is TBLT able to improve the students' skill in writing descriptive text? 2). To what extent does TBLT affect the students writing skill development? The first question was examined using quantitative approach which specifically used pre-experimental method. On the other hand, the second question was answered using qualitative approach which specifically used descriptive method. It means that the quantitative data will be followed-up with qualitative explanations. Besides, this study involved 27 senior high students as the participants who were purposively selected among the second grade students of Madani Alauddin Pao-Pao Senior high school. Furthermore, the data were gathered by using two instruments; tests and interviews. The test is a writing test which was given to reveal the students' skills in writing descriptive text before and after treatments. Semi-structured interviews were used to confirm the contributing factors to the achievement of the students' skills in writing descriptive text.

\section{FINDING AND DISCUSSION}

\section{A. The Effect of TBLT on the Students' Skill in Writing Descriptive Texts}


To respond to the issue, the results of writing tests were used. The writing test was given twice, before giving the TBLT based-treatments (pre-test) and after giving the TBLT based-treatments (post-test). These tests' results are quantitatively presented as follows:

\section{The Results of the Pre-Test}

The first writing test (Pre-Test) was given to twenty-seven (27) students one day before teaching the students using the Task-Based Language Teaching (TBLT) materials. The test took place on September 05, 2019 for about 30 minutes. The results of the test are shown in Table 1 as follows:

TABLE 1

THE RESUlT OF PRE-TEST

\begin{tabular}{|c|c|c|c|c|c|c|c|}
\hline \multirow{3}{*}{ No } & \multirow{3}{*}{$\begin{array}{l}\text { Students' } \\
\text { Number }\end{array}$} & \multicolumn{5}{|c|}{ Experimental Class } & \multirow{3}{*}{ Total } \\
\hline & & \multicolumn{5}{|c|}{ Writing Components } & \\
\hline & & $\begin{array}{l}\text { Organiza } \\
\text { tion }\end{array}$ & Content & Grammar & Punctuation & Vocabulary & \\
\hline 1 & S001 & 15 & 15 & 15 & 15 & 15 & 75 \\
\hline 2 & S002 & 15 & 15 & 12 & 15 & 12 & 69 \\
\hline 3 & S003 & 15 & 15 & 14 & 14 & 12 & 70 \\
\hline 4 & S004 & 15 & 14 & 12 & 15 & 12 & 68 \\
\hline 5 & S005 & 15 & 15 & 12 & 14 & 12 & 68 \\
\hline 6 & S006 & 14 & 12 & 11 & 12 & 12 & 61 \\
\hline 7 & S007 & 12 & 14 & 11 & 12 & 12 & 61 \\
\hline 8 & S008 & 12 & 12 & 11 & 12 & 10 & 57 \\
\hline 9 & S009 & 12 & 12 & 11 & 12 & 12 & 59 \\
\hline 10 & S010 & 14 & 12 & 11 & 12 & 12 & 61 \\
\hline 11 & S011 & 11 & 11 & 11 & 11 & 11 & 55 \\
\hline 12 & S012 & 11 & 11 & 11 & 11 & 11 & 55 \\
\hline 13 & S013 & 11 & 11 & 7 & 11 & 11 & 51 \\
\hline 14 & S014 & 11 & 11 & 7 & 11 & 10 & 50 \\
\hline 15 & S015 & 12 & 10 & 6 & 12 & 10 & 50 \\
\hline 16 & S016 & 12 & 11 & 6 & 11 & 10 & 50 \\
\hline 17 & S017 & 12 & 11 & 7 & 10 & 10 & 50 \\
\hline 18 & S018 & 11 & 11 & 7 & 11 & 8 & 48 \\
\hline 19 & S019 & 11 & 11 & 7 & 11 & 8 & 48 \\
\hline 20 & S020 & 11 & 11 & 6 & 11 & 7 & 46 \\
\hline 21 & S021 & 11 & 11 & 6 & 10 & 10 & 48 \\
\hline 22 & S022 & 10 & 10 & 6 & 10 & 10 & 46 \\
\hline 23 & S023 & 10 & 10 & 6 & 10 & 6 & 42 \\
\hline 24 & S024 & 10 & 10 & 6 & 6 & 6 & 38 \\
\hline 25 & S025 & 10 & 10 & 6 & 6 & 6 & 38 \\
\hline 26 & S026 & 10 & 8 & 5 & 6 & 6 & 35 \\
\hline 27 & S027 & 8 & 6 & 5 & 6 & 5 & 30 \\
\hline & verage & 11,9 & 11,4 & 8,7 & 11 & 9,8 & 52,9 \\
\hline
\end{tabular}

The results of the pre-test as shown in Table 1, indicate that the average score achieved by the students is 52.9 meaning that the level of the students' skills in writing descriptive test is in fair level before the treatment (teaching them by using Task-Based Language Teaching (TBLT) materials). The pre-test was also processed and analyzed by using SPSS application which finally resulted in the following pre-test description:

TABLE 2

SPSS ANALYSIS OF PRE-TEST RESULT

\begin{tabular}{|c|c|c|}
\hline \multicolumn{3}{|c|}{ Statistics } \\
\hline \multicolumn{3}{|c|}{ PRE TEST } \\
\hline \multirow{2}{*}{$\mathrm{N}$} & Valid & 27 \\
\hline & Missing & 0 \\
\hline \multicolumn{2}{|c|}{ Mean } & 52,9259 \\
\hline \multicolumn{2}{|c|}{ Median } & 50,0000 \\
\hline \multicolumn{2}{|c|}{ Std. Deviation } & 11,38125 \\
\hline \multicolumn{2}{|c|}{ Variance } & 129,533 \\
\hline \multicolumn{2}{|c|}{ Minimum } & 30,00 \\
\hline \multicolumn{2}{|c|}{ Maximum } & 75,00 \\
\hline
\end{tabular}

\section{The Results of the Post-Test}

The post-test was also in writing test given to the twenty-seven (27) students on October 03, 2019 after receiving several treatments using Task-Based Language Teaching (TBLT) materials. The results of the test are shown in Table 3 as follows: 
TABLE 3

THE RESUlt OF POST-Test

\begin{tabular}{|c|c|c|c|c|c|c|c|}
\hline \multirow{2}{*}{ No } & \multirow{2}{*}{$\begin{array}{c}\text { Students' } \\
\text { Number }\end{array}$} & \multicolumn{7}{|c|}{ Writing Components } & \multirow{2}{*}{ Total } \\
\cline { 3 - 8 } & & $\begin{array}{c}\text { Organiza } \\
\text { tion }\end{array}$ & Content & Grammar & Punctuation & Vocabulary & \\
\hline 1 & S001 & 17 & 17 & 12 & 15 & 15 & 76 \\
\hline 2 & S002 & 15 & 15 & 12 & 15 & 14 & 71 \\
\hline 3 & S003 & 17 & 15 & 12 & 17 & 14 & 75 \\
\hline 4 & S004 & 15 & 15 & 12 & 14 & 12 & 68 \\
\hline 5 & S005 & 14 & 14 & 11 & 14 & 12 & 65 \\
\hline 6 & S006 & 14 & 14 & 11 & 14 & 12 & 65 \\
\hline 7 & S007 & 14 & 14 & 11 & 14 & 12 & 65 \\
\hline 8 & S008 & 15 & 17 & 12 & 14 & 12 & 70 \\
\hline 9 & S009 & 14 & 14 & 11 & 14 & 12 & 65 \\
\hline 10 & S010 & 17 & 17 & 14 & 17 & 15 & 80 \\
\hline 11 & S011 & 14 & 14 & 11 & 14 & 12 & 65 \\
\hline 12 & S012 & 15 & 14 & 11 & 14 & 11 & 65 \\
\hline 13 & S013 & 15 & 15 & 11 & 15 & 12 & 68 \\
\hline 14 & S014 & 14 & 12 & 8 & 14 & 12 & 60 \\
\hline 15 & S015 & 14 & 15 & 8 & 14 & 12 & 63 \\
\hline 16 & S016 & 15 & 15 & 8 & 15 & 12 & 65 \\
\hline 17 & S017 & 14 & 14 & 8 & 14 & 10 & 60 \\
\hline 18 & S018 & 12 & 12 & 6 & 14 & 6 & 50 \\
\hline 19 & S019 & 15 & 15 & 8 & 15 & 12 & 65 \\
\hline 20 & S020 & 15 & 15 & 8 & 17 & 12 & 67 \\
\hline 21 & S021 & 15 & 14 & 8 & 14 & 12 & 63 \\
\hline 22 & S022 & 12 & 12 & 6 & 12 & 6 & 48 \\
\hline 23 & S023 & 17 & 17 & 12 & 17 & 12 & 75 \\
\hline 24 & S024 & 14 & 14 & 8 & 14 & 12 & 62 \\
\hline 25 & S025 & 12 & 12 & 8 & 12 & 11 & 55 \\
\hline 26 & S026 & 12 & 11 & 5 & 11 & 6 & 45 \\
\hline 27 & S027 & 17 & 17 & 12 & 15 & 14 & 75 \\
\hline & Average & 14,6 & 14,4 & 9,8 & 14,4 & 11,6 & 64,8 \\
\hline & & & & & & & \\
\hline
\end{tabular}

Table 3 indicates that the students achieve 64.8 as the total average score in the post-test meaning that the level of the students' skills in writing descriptive text is in good level after getting treatments using Task-Based Language Teaching (TBLT). The data gathered in the post-test were also processed and analyzed by using SPSS and the results of the analysis were illustrated in the following statistical description:

TABLE 4

SPSS ANALYSIS POST-TEST RESULT

\begin{tabular}{|c|c|c|}
\hline \multicolumn{3}{|c|}{ Statistics } \\
\hline \multicolumn{3}{|c|}{ POST_TEST } \\
\hline \multirow{2}{*}{$\mathrm{N}$} & Valid & 27 \\
\hline & Missing & 0 \\
\hline \multicolumn{2}{|c|}{ Mean } & 64,8519 \\
\hline \multicolumn{2}{|c|}{ Median } & 65,0000 \\
\hline \multicolumn{2}{|c|}{ Std. Deviation } & 8,34222 \\
\hline \multicolumn{2}{|c|}{ Variance } & 69,593 \\
\hline \multicolumn{2}{|c|}{ Minimum } & 45,00 \\
\hline \multicolumn{2}{|c|}{ Maximum } & 80,00 \\
\hline
\end{tabular}

\section{The Overall Results of the Pre-Test and the Post-Test}

As mentioned earlier that the pre- and the post-test were used to examine the students' skill in writing descriptive texts gained from the treatments using the Task-Based Language Teaching. The comparison between the students' posttest scores and their pre-test scores had shown that the treatments using TBLT was successful in developing the students' skills in writing descriptive texts. The comparison is shown in Table 5 as follows: 
TABLE 5

TEST SCORES COMPARISON BETWEEN PRE-TEST AND POST-TEST

\begin{tabular}{|c|c|c|c|}
\hline \multirow{2}{*}{ No } & \multirow{2}{*}{ Students' Number } & \multicolumn{2}{|c|}{ Total pre- and post-test scores } \\
\hline & & Pre-test & Post-test \\
\hline 1 & S001 & 75 & 76 \\
\hline 2 & S002 & 69 & 71 \\
\hline 3 & S003 & 70 & 75 \\
\hline 4 & S004 & 68 & 68 \\
\hline 5 & S005 & 68 & 65 \\
\hline 6 & S006 & 61 & 65 \\
\hline 7 & S007 & 61 & 65 \\
\hline 8 & S008 & 57 & 70 \\
\hline 9 & S009 & 59 & 65 \\
\hline 10 & S010 & 61 & 80 \\
\hline 11 & S011 & 55 & 65 \\
\hline 12 & S012 & 55 & 65 \\
\hline 13 & S013 & 51 & 68 \\
\hline 14 & S014 & 50 & 60 \\
\hline 15 & S015 & 50 & 63 \\
\hline 16 & S016 & 50 & 65 \\
\hline 17 & S017 & 50 & 60 \\
\hline 18 & S018 & 48 & 50 \\
\hline 19 & S019 & 48 & 65 \\
\hline 20 & S020 & 46 & 67 \\
\hline 21 & S021 & 48 & 63 \\
\hline 22 & S022 & 46 & 48 \\
\hline 23 & S023 & 42 & 75 \\
\hline 24 & S024 & 38 & 62 \\
\hline 25 & S025 & 38 & 55 \\
\hline 26 & S026 & 35 & 45 \\
\hline 27 & S027 & 30 & 75 \\
\hline & Average & 52,9 & 64,8 \\
\hline & Description & Fair & Good \\
\hline
\end{tabular}

Table 5 shows that all the students in the experimental group have significant improvement in their gained score before and after treatment. The students' progress in learning can be watched after comparing the students' gain score in pre-test (52.9) and the students' gain score in post-test (64.8). If both gain scores are given description by referring to the students' writing skills before and after treatment, we may then state that the level of the students' writing skills increases from fair to good qualification.

\section{Assumption Test}

Before testing this research hypothesis, it is important to test the sample distribution for the sake of finding out whether the sample is normal or not. This test is also known as the normality test. The normality test aims to test all hypothesis that test a null against an alternative hypothesis (Abidin \& Kaharuddin. (2021). The result of normality test covers two statements of the hypothesis test namely:

Ho $=$ the null hypothesis

The sample is recognized to be normal distribution when significant value is greater than $0,05(\operatorname{sig}>0,05)$

$\mathrm{H} 1=$ the alternative hypothesis

The sample is regarded to be not normally distributed when the significant value is less than 0.05 (sig $<0,05)$

To test the normality of sample distribution in this research, the Kolmogorov-Smirnov statistical test is then used as shown in Table 6 as follows:

TABLE 6

ONE-SAMPLE KOLMOGROV-SMIRNOV TEST

\begin{tabular}{|l|l|r|r|}
\hline \multicolumn{4}{|c|}{ One-Sample Kolmogorov-Smirnov Test } \\
\hline \multirow{4}{|c|}{$\mathrm{N}$} & PRE_TEST & POST_TEST \\
\hline \multirow{2}{*}{ Normal Parameters ${ }^{\mathrm{a}, \mathrm{b}}$} & Mean & 27 & 27 \\
\cline { 2 - 4 } & Std. Deviation & 11,38125 & 8,34222 \\
\hline \multirow{3}{*}{ Most Extreme Differences } & Absolute &, 123 &, 174 \\
\cline { 2 - 4 } & Positive &, 123 &, 123 \\
\cline { 2 - 4 } & Negative &,- 093 &,- 174 \\
\hline Kolmogorov-Smirnov Z &, 638 &, 903 \\
\hline Asymp. Sig. (2-tailed) &, 811 &, 389 \\
\hline a. Test distribution is Normal. \\
\hline b. Calculated from data.
\end{tabular}


Referring to Table 6, it is clearly seen that Significant value of the pre-test $=0,811>0,05$, which means no enough evidence to reject the null hypothesis and we can finally claim that the sample is normally distributed. On the other hand, Significant value of the post-test $=0,389>0,05$ which means that the sample in the post-test is also normally distributed.

\section{Independent T-Test}

Knowing that the samples of the pre-test and the post-test are normally distributed, the implication of the Task-Based Language Teaching (TBLT) on the students' writing skills is tested by using the following hypotheses namely:

If Sig. (2-tailed) < 0.05, Ho (null hypothesis) is rejected and H1 (alternative hypothesis) is accepted.

If Sig. (2-tailed) > 0.05, Ho (the null hypothesis) is accepted and H1 (alternative hypothesis) is rejected.

In order to test the hypotheses, the paired sample t-test is then used to determine whether to accept or to reject the null hypothesis.

TABLE 7

PAIRED SAMPLES T-TEST

\begin{tabular}{|c|c|c|c|c|c|c|c|c|c|}
\hline \multicolumn{10}{|c|}{ Paired Samples Test } \\
\hline & & \multicolumn{5}{|c|}{ Paired Differences } & \multirow[t]{3}{*}{$\mathrm{t}$} & \multirow[t]{3}{*}{$\mathrm{df}$} & \multirow{3}{*}{$\begin{array}{l}\text { Sig. }(2- \\
\text { tailed) }\end{array}$} \\
\hline & & \multirow[t]{2}{*}{ Mean } & \multirow[t]{2}{*}{$\begin{array}{c}\text { Std. } \\
\text { Deviation }\end{array}$} & \multirow[t]{2}{*}{$\begin{array}{l}\text { Std. Error } \\
\text { Mean }\end{array}$} & \multicolumn{2}{|c|}{$\begin{array}{l}\text { 95\% Confidence Interval of the } \\
\text { Difference }\end{array}$} & & & \\
\hline & & & & & Lower & Upper & & & \\
\hline $\begin{array}{l}\text { Pair } \\
1\end{array}$ & $\begin{array}{l}\text { POST TEST - PRE } \\
\text { TEST }\end{array}$ & 11,92593 & 10,60089 & 2,04014 & 7,73235 & 16,11950 & 5,846 & 26 &, 000 \\
\hline
\end{tabular}

With regard to the table above, it is found that SPSS output for paired sample t-test is Sig. (2-tailed) $=0,000<0,05$. This implies that the treatment has a significant main effect on the students' writing skills achievement. The null (Ho) is therefore rejected and the alternative hypothesis (H1) is accepted. Therefore, it can be concluded that there is an average difference between Pre-Test and Post-Test learning outcomes, which means that the use of Task-Based Language Teaching (TBLT) method brings about significant effect on the development of the students' skills in writing descriptive texts. This study has provided a strong support and evidences of some previous studies (Fiori, M. L. 2005, Kaharuddin, A. 2014, Lai, C., \& Lin, X. 2015, Hao, D. T. T. 2017, Kadaruddin, et.al. 2020) that investigating the effectiveness of TBLT on language skills' development is a promising result.

\section{B. Contributing Factors to the Development of the Students' Skills in Writing Descriptive Texts}

To determine the contributing factors, data from interviews were used. The Interviews were given to the twentyseven (27) students in the experimental class. The results of the data analysis showed that there are 5 contributing factors to the development in the students' writing skill, among other things: Students' Interest, Teacher's Strategy, Teacher's Media, Classroom Environment, and Students' Learning Strategy. Detailed information can be gained in Table 8 as follows:

TABLE 8

CONTRIBUting Factors To The DEvelopment In THE StUdents’ Writing SKILL

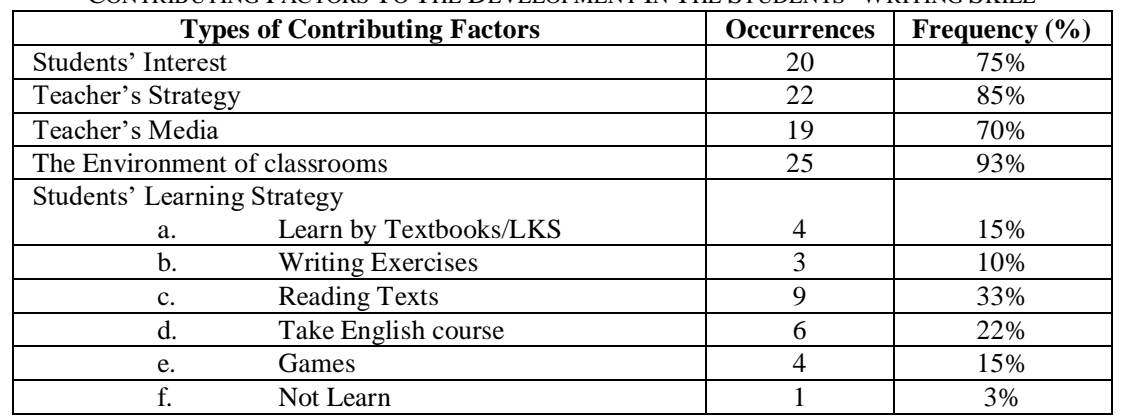

\section{The Students' Interest}

As for the students, interest in writing lesson takes up larger portion of the factors affecting the development in the students' writing skill. Due to the interest factor, the students give strong to the writing lesson that positively affects their understanding on the lesson. The data in Table 8 indicate that 20 out of 27 students have interest in writing lesson. S 005)

"I am interested in learning all skills of English because English is an international language that is widely used in various fields. My interest in learning all skills of English makes focus when my English teacher is teaching me. Besides, I get a number of English vocabulary from the teacher's lessons (Sari, A. A. I. 2020)"

The statement indicates that the students' interest in the English lessons, makes them largely focus and make effort to understand the lessons including writing skills lessons. Similar statements are also given by other students in the interview as follows: 


\section{S 012)}

"I am very interested in writing skill and I also think that writing is one of the skills that I must master because it is very important after speaking skills. Therefore, I try to memorize a large number of English vocabulary for completing writing assignments from the teacher (Sari, A. A. I. 2020:64)"

S 016)

"I always prefer writing to speaking in front of many people, so I feel writing skill is more important than speaking. Now I take English lessons to learn more grammar rules and to enrich my English vocabulary (Sari, A. A. I. 2020:65)"

The statements indicate that the students' interest makes a positive contribution to the development of the students' skill in writing descriptive text. The level of students' interest in a particular subject can increase student motivation in learning. In this regard, Lipstein, R. L., \& Renninger, K. A. (2006) state that individual interest may mediate attention, goals, motivations and learning strategies with respect to particular content. In a nut shell, students' interest in learning writing skills becomes a motivation to learn more and make them focus on learning the writing lessons in the classroom As previous researchers assert that interest can affect the quality of students' learning achievement in a certain subject (Arafah, B. \& Kaharuddin 2019). In addition, the students are found to learn more when they are motivated and interested in the course (Marks 2000; Young et al., 2003).

\section{Teachers' Teaching Strategies}

The data in table 8 reflect that the teachers used two teaching strategies namely: giving the teaching materials directly and giving assignment to practice the teaching materials. The students really like the teaching strategies According to the students both strategies have made them understand the lessons easily. The following statements illustrate how teachers' teaching strategies affect the students' achievement in learning English.

\section{$\mathrm{S}$ 002)}

"The way of our English teacher teaching in the classroom makes us understand the English lessons easily. The teacher explains the lessons clearly, gives relevant examples, motivates us to participate and ask questions about the lessons. In my opinion such strategy really helps me understand the English lessons, because the teacher gives what the students need. (Sari, A. A. I. 2020:66)"

Other statements were also given by the other students in the interview. They complained about the teachers' bad strategies when teaching English lessons.

S 006)

"Sometimes the teacher explains his English lessons too fast that I frequently find it difficult to under the lessons. When the teacher gives us tasks from the lessons, I cannot complete the tasks because I do not understand the lessons from the beginning. (Sari, A. A. I. 2020:66)"

S 011)

"I think that I like an English teacher who explains his lessons slowly and clearly. After that he gives us assignments about the lessons. (Sari, A. A. I. 2020:67)"

The statements indicate that the English teachers' teaching strategies give a major contribution to the development of students' writing skills. The teaching strategies not only play an important role in helping the students learn easily and effectively, but also encourage them to learn seriously to increase their skills and knowledge of English. In other words, the teachers' strategies in teaching and learning process could considerably influence the students' progress in language acquisition (Yassi, A. H. and Kaharuddin 2018).

\section{Teacher's Media in Teaching}

Using teaching media also affects the English teachers' success in teaching their students. Therefore, the teachers are required to select suitable media for particular language skill. For example, English songs can be used as media to teach listening skill or pronunciation skill. In teaching writing descriptive texts, the teachers simply used textbooks and worksheets (LKS). These simple media were very useful to some students.

S 015)

"I like the media used by the English teacher such as the textbooks or the worksheets. From textbooks, I can learn the lessons easily because I can read the lessons carefully. On the other hand, the worksheets gives me opportunity to practice the lessons for better understanding. (Sari, A. A. I. 2020:68)"

Another similar statement was also given by a student in the interview as follows:

\section{S 018)}

"My teacher usually distributes worksheets related to the lessons to the students, and I find it helpful to understand the lessons because I can take them home which gives me more opportunity to learn. (Sari, A. A. I. 2020:68)"

By referring to the statements, we may assert that the media used by the teacher in teaching writing skill has an important role in making the students understand the writing lessons easily. As Ismail., Sunubi, A. H., Halidin, A., Nanning \& Kaharuddin (2020) stated that the appropriate media used by the English teacher when teaching will positively support teaching and learning process which is in turn able to stimulate the students' interest and motivation to learn English earnestly. 


\section{Classroom Environment}

The data in Table 8 also indicate that the students have a problem regarding the classroom environment. The noisy classroom became one of the biggest problems for them because it not only disturbed their focus and concentration during learning, but also negatively affects their understanding on the lessons. These are their statements:

S 003)

"The biggest disturbance for me when studying is the noise in the classroom. When some friends don't pay attention to the teacher's lesson and are busy with talking about their own personal business one another in the classroom. I lose focus and it sometimes makes me not understand what the teacher is talking about (Sari, A. A. I. 2020:69)"

S 009)

"I really can't understand the lessons from the teacher if many students make noise in the classroom, some friends also often talk to me, so it makes me miss the teacher's explanations (Sari, A. A. I. 2020:69)",

S 020)

"I often lose my concentration in learning because my classmates often disturb me by asking about the meanings of some difficult vocabulary, even though each student has a dictionary but they are lazy to search for the vocabulary themselves. Fortunately sometimes the teacher reprimands them (Sari, A. A. I. 2020:70)"

From the students' statements, it stands to reason for saying that the environment of the classroom when learning writing skill has a big influence on students' focus on the lessons. This fact is relevant to what Gazmuri, Manzi, \& Paredes (2015) state that the surrounding environment, the way that teachers manage their classrooms and school discipline are generally regarded as crucial factors in students' learning experiences. In addition, Hannah (2013) also gives similar comment about it that the classroom environment plays a crucial role in keeping students engaged and allowing them to be successful within the classroom.

\section{Students' Learning Strategy}

The data in Table 8 show that the students basically use certain learning strategies to learn writing skill. Most of the students (9 out of 27) like reading English texts such as novels, comics, stories, or news to enrich their English vocabulary. On the other hand, 6 out of 27 students take English course at English training institutions out of their school. These things seem to be the most dominant strategy used by the students to improve their English skills. They believe that having knowledge and skills of English by the strategies has enabled them to understand the lessons on writing descriptive texts easily. The students' statements are presented as follows:

S 005)

"I usually learn vocabulary by reading comics, because nowadays good online comics use mostly English, so I try to read and find the meaning of the new vocabulary that I get (Sari, A. A. I. 2020:71)"

S 002)

"I study outside of school by taking English lessons, I take lessons to better understand learning materials and also a lot of material that I didn't get at school but I got at my English tutoring (Sari, A. A. I. 2020:70)"

The statements above indicate that the students use certain strategies to deal with problems in learning English at schools. Some of them use particular ways to improve their English skills before receiving lessons on English writing. Some prefer reading English texts in their leisure time to enrich their English vocabulary, and some prefer to take English lessons at language center after going back from schools. This is what we recognize as the students' learning strategy. Therefore, learning strategy in this context may be defined as the students' way of dealing with learning a lesson or completing a task (Schumaker, J. B., \& Deshler, D. D. 1992). The students' Learning strategies outside the classrooms have given a great contribution to the development of their skill in writing descriptive texts. Huy (2015) stated that self-study at home plays an important part since it prepares students' knowledge before coming to the classroom, and after that it helps students review what they learned.

\section{CONCLUSION}

The results of data analysis from both quantitative (writing test) and qualitative data (questionnaires and interviews) showed that the implementation of Task-Based Language Teaching (TBLT) in the classroom is effective in developing the students' skills in writing descriptive texts. The students' skill level in writing descriptive text was fair before but after the treatment with Task Based Language Teaching (TBLT), the students' skill level increases to good level. It means there was an improvement in the students' writing achievement before and after the treatment. On the other hand, the result of the Questionnaires and the Interviews showed that there are 5 contributing factors to the development of students' skills in writing descriptive texts, among other things; Students' Interest, Teacher's Strategy, Teacher's Media, Classroom Environment, and Students' Learning Strategy. The overall findings from this research prove that TBLT has produced positive effect in the students' skill achievement in writing descriptive texts, but not for the other types of writing particularly, academic writing, or other skills of English. We recommend that English language teachers provide more opportunities to learn this method which is expected enable them to understand and apply it in their English pedagogy. Having the knowledge of TBLT is believed able to build up the teachers' confidence and pedagogic skill in their classrooms (Lin, T. B., \& Wu, C. W. 2012). 


\section{REFERENCES}

[1] Abidin \& Kaharuddin. (2021). Analysis of Syariah Credit Card from Islamic Economic Perspective: Evidence From BNI Bank In Indonesia. Academy of Strategic Management Journal, 20(4S), 1-11.

[2] Andi, K., \& Arafah, B. (2017). Using needs analysis to develop English teaching materials in initial speaking skills for Indonesian college students of English. The Turkish Online Journal of Design, Art and Communication (TOJDAC), Special Edition, 419-436. https://doi.org/10.7456/1070ASE/045

[3] Apriliana, R., Candra, M., \& Subroto, G. (2020). Students' Difficulties in Writing Descriptive Text: An Analysis Study. Student Online Journal (SOJ) UMRAH-Keguruan dan Ilmu Pendidikan, 1(1), 348-352.

[4] Arafah, B. \& Kaharuddin (2019). The Idol: A Model for Incorporating Literature in ELT. KnE Social Sciences, 20 (1), $43-59$. https://doi.org/10.18502/kss.v3i19.4829

[5] Arafah, B., \& Kaharuddin, (2019). The Representation of Complaints in English and Indonesian Discourses. Opción, 35, 501517. https://doi.org/10.18502/kss.v3i19.4829

[6] Bahar, A. K. (2013). The Communicative Competence-Based English Language Teaching. Yogyakarta: TrustMedia.

[7] Bahar, A. K. (2014). Transactional Speaking: A Guide to Improve Transactional Exchange Skills in English for Group Discussions (GD) and Interviews. Samata Gowa: Gunadarma Ilmu.

[8] Bahar, A. K., \& Latif, I. (2019). Society-Based English Community (Sobat): EFL Learners' Strategy in Learning and Practicing English outside the Walls. Jurnal ilmu budaya, 7(2), 255-265.

[9] Bello, T. (1997). Improving ESL Learners' Writing Skills. ERIC Digest.

[10] Braine, G., \& Yorozu, M. (1998). Local area network (LAN) computers in ESL and EFL writing classes: Promises and realities. JALT Journal, 20(2), 47-59.

[11] Candlin, C. (1987). Towards task-based language learning. Language learning tasks, 7, 5-22.

[12] Dailey, A. (2009). Implementing task-based language teaching in Korean classrooms. University of Birmingham, 1-20.

[13] Ellis, R. (2003). Task-based language learning and teaching. Oxford University Press.

[14] Fiori, M. L. (2005). The development of grammatical competence through synchronous computer-mediated communication. Calico Journal, 567-602. https://doi.org/10.1558/cj.v22i3.567-602

[15] Gazmuri, C., Manzi, J., \& Paredes, R. D. (2015). Classroom discipline, classroom environment and student performance in Chile. Cepal Review. Page 103-106. https://doi.org/10.18356/bc44a854-es

[16] Hannah, R. (2013). The Effect of Classroom Environment on Student. Honors Theses, 12 (6), 1-22.

[17] Hashemi, M., Azizinezhad, M., \& Darvishi, S. (2012). Using task-based language teaching, learning practically in English classes. Procedia-Social and Behavioral Sciences, 31, 526-529. https://doi.org/10.1016/j.sbspro.2011.12.098

[18] Hasyim, M., Kuswarini, P., \& Kaharuddin. (2020). Semiotic Model for Equivalence and Non-Equivalence In Translation, Humanities \& Social Sciences Reviews, 8, (3), 381-391. https://doi.org/10.18510/hssr.2020.8341

[19] Hao, D. T. T. (2017). Task-based language teaching: An insight into teacher practice. International Journal of Education, Culture and Society, 2(4), 126-131. https://doi.org/10.11648/j.ijecs.20170204.14

[20] Hasjim, M., Arafah, B., Kaharuddin, S. V., \& Genisa, R. A. A. (2020). Principles behind Semantic Relation between Common Abbreviations and their Expansions on Instagram. International Journal of Criminology and Sociology, 9, 2270-2276

[21] Herdi, H. (2015). An Analysis on Factors Influencing the Students' writing Skill. ELT-Lectura, 2(2), 1-4. https://doi.org/10.31849/elt-lectura.v2i2.465

[22] Husna, L. (2017). An Analysis of Students' Writing Skill in Descriptive Text at Grade X1 Ipa 1 Of Man 2 Padang. Jurnal Ilmiah Pendidikan Scholastic, 1(1), 16-28. https://doi.org/10.36057/jips.v1i1.281

[23] Huy, N. T. (2015). Problems affecting learning writing skill of grade 11 at Thong Linh high school. Asian Journal of Educational Research, 3(2), 53-67.

[24] Ismail., Sunubi, A. H., Halidin, A., Nanning \& Kaharuddin. (2020). Paraphrasing Technique To Develop Skill for English Writing Among Indonesian College Students of English. Sys Rev Pharm, 11(11), 291-297.

[25] Javed, M., Juan, W. X., \& Nazli, S. (2013). A Study of Students' Assessment in Writing Skills of the English Language. Online submission, 6(2), 129-144.

[26] Jeon, I. J., \& Hahn, J. W. (2006). Exploring EFL teachers' perceptions of task-based language teaching: A case study of Korean secondary school classroom practice. Asian EFL Journal, 8(1), 123-143.

[27] Johnstone, K. M., Ashbaugh, H., \& Warfield, T. D. (2002). Effects of repeated practice and contextual-writing experiences on college students' writing skills. Journal of educational psychology, 94(2), 305-315. https://doi.org/10.1037/0022-0663.94.2.305

[28] Kadaruddin, Arafah, B., Ahmad, D., Kaharuddin, Iska. (2020). Word Wall Media: An Effective Teaching Technique to Enrich Students' Vocabulary in Secondary Level of Education, International Journal of Advanced Science and Technology, 29 (5), 13228-13242.

[29] Kaharuddin, A. (2014). Interactional Speaking a Guide to Enhance Natural Communication Skills in English: Yogyakarta.

[30] Kaharuddin, N. (2014). The problems of Indonesian college EFL Learners in Listening Comprehension. Jurnal ilmu budaya, 2(2), 385-397.

[31] Kaharuddin, A., \& Latif, I. (2017). The Essential of Discourse Analysis for Teaching English as a Foreign Language. Yogyakarta: Trust Media Publishing.

[32] Kaharuddin, A. (2018). The communicative grammar translation method: a practical method to teach communication skills of English. ETERNAL (English, Teaching, Learning, and Research Journal), 4(2), $232-254$. https://doi.org/10.24252/Eternal.V42.2018.A8

[33] Kaharuddin, Hikmawati, Arafah, B. (2019). Needs Analysis on English for Vocational Purpose for Students of Hospitality Department. KnE Social Sciences, 2019, 344-387.

[34] Kaharuddin, A. (2019). The Power of English: Recognizing and Utilizing the Tremendous Impact of the English Language on the Community. English Language Teaching for EFL Learners, 1(1), 39-48. https://doi.org/10.24252/elties.v1i1.7625 
[35] Kaharuddin., \& Hasyim, M. (2020). The Speech Act of Complaint: Socio-Cultural Competence Used by Native Speakers of English and Indonesian. International Journal of Psychosocial Rehabilitation, 24(6), 14016-14028. doi: 10.37200/ijpr/v24I6/pr261351

[36] Kaharuddin, K., \& Rahmadana, A. (2020). Problem-Based Group Discussion: An Effective ELT Technique to Improve Vocational High School Students' Transactional Speaking Skills. Jurnal Ilmu Budaya, 8(2), $247-258$. https://doi.org/10.34050/jib.v8i2.11032

[37] Kaharuddin, Ahmad, D, Mardiana, Rusni (2020). Contributions of Technology, Culture, And Attitude To English Learning Motivation During Covid -19 Outbreaks. Systematic Reviews in Pharmacy, 11 (11), 76-84. doi:10.31838/srp.2020.11.13

[38] Kellogg, R. T., \& Raulerson, B. A. (2007). Improving the writing skills of college students. Psychonomic bulletin \& review, 14(2), 237-242. https://doi.org/10.3758/BF03194058

[39] Lai, C., \& Lin, X. (2015). Strategy training in a task-based language classroom. The Language Learning Journal, 43(1), 20-40. https://doi.org/10.1080/09571736.2012.681794

[40] Lipstein, R. L., \& Renninger, K. A. (2006). "Putting Things into Words": The Development of 12-15-Year-Old Students' Interest for Writing. In Writing and motivation (pp. 113-140). Brill. https://doi.org/10.1163/9781849508216_008

[41] Lin, T. B., \& Wu, C. W. (2012). Teachers' perceptions of task-based language teaching in English classrooms in Taiwanese junior high schools. TESOL Journal, 3(4), 586-609. https://doi.org/10.1002/tesj.35

[42] Liu, Y., Mishan, F., \& Chambers, A. (2021). Investigating EFL teachers' perceptions of task-based language teaching in higher education in China. The Language Learning Journal, 49(2), 131-146. https://doi.org/10.1080/09571736.2018.1465110

[43] Masitoh, S., \& Suprijadi, D. (2015). Improving students' ability in writing descriptive text using genre based approach (GBA) at the eighth grade students of SMP Islam Terpadu Fitrah Insani. Eltin journal, Journal of English Language Teaching in Indonesia, 3(1). 38-52.

[44] Nunan, D. (2003). The impact of English as a global language on educational policies and practices in the Asia-Pacific Region. TESOL quarterly, 37(4), 589-613. https://doi.org/10.2307/3588214

[45] Potradinata, S. L. A. (2018). An analysis of student's descriptive text writing in systemic functional linguistic (SFL) perspectives. International Journal of Languages, Literature and Linguistics, 4(2), $125-131$. https://doi.org/10.18178/IJLLL.2018.4.2.161

[46] Richards, J. C. (2005). Communicative language teaching today (pp. 22-26). Singapore: SEAMEO Regional Language Centre.

[47] Samuda, V., \& Bygate, M. (2008). Tasks in second language learning. Basingstoke: Palgrave Macmillan. https://doi.org/10.1057/9780230596429

[48] Sari, A. A. I. (2020). Task Based Language Teaching (TBLT) in the classroom: An Effort to Teach Students' Writing Skills in Writing Descriptive Text at Second Grade of MA Madani Alauddin (Doctoral dissertation, Universitas Islam Negeri Alauddin Makassar).

[49] Schumaker, J. B., \& Deshler, D. D. (1992). Validation of learning strategy interventions for students with learning disabilities: Results of a programmatic research effort. In Contemporary intervention research in learning disabilities (pp. 22-46). Springer, New York, NY. https://doi.org/10.1007/978-1-4612-2786-1_2

[50] Siahaan, J. (2013). An analysis of students' ability and difficulties in writing descriptive texts. Journal of English and Education, 1(1), 114-121.

[51] Wesley, A., Oshima, A., \& Hogue, A. (1996). Introduction to Academic Writing, Second Edition (The Longman Academic Writing Series). Addison Wesley Publishing Company.

[52] Yassi, A. H. and Kaharuddin. (2018). Syllabus Design Of English Language Teaching. Jakarta: Prenada Media.

[53] Yoandita, P. E. (2019). An Analysis of Students' ability and Difficulties in Writing Descriptive Text. Jurnal JOEPALLT (Journal of English Pedagogy, Linguistics, Literature, and Teaching), 7(1), 1-14. https://doi.org/10.35194/jj.v7i1.534

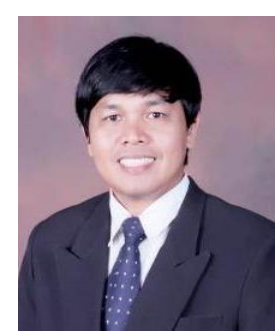

Kaharuddin was born in Makassar, Indonesia; on August $14^{\text {th }}, 1975$. He got his master's degree in English Language Studies in 2004 and his doctoral degree in Applied Linguistics in 2014, both from Hasanuddin University of Makassar, Indonesia. He is currently a senior lecturer in English Language Teaching and Linguistics at the English Education Department, Faculty of Education and Teacher Training, Universitas Islam Negeri (UIN) Alauddin Makassar, Indonesia. He is the author of a number of books, including: Syllabus Design for English Language Teaching, Prenada Media (2018); It's All About Transactional Speaking Skills, Eliva Press, Moldova Europe (2021); and Linguistics: Basic theory and Roles in ELT, Prenada Media (2021). His research focuses on English education and Linguistics.

Dr. Kaharuddin is currently a member of ASIA TEFL Association, Busan, South Korea.

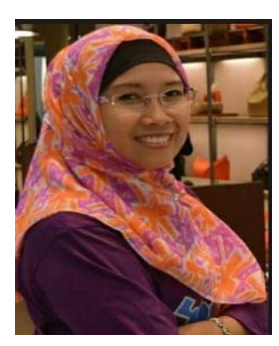

Mardiana Nurdin, a lecturer in English Education, was born in Pinrang, South Sulawesi on August, $15^{\text {th }}$ 1969. She obtained her Bachelor Degree in Institute of Teacher Training of Ujung Pandang in 1993. She continued and finished her Master Degree in Hasanuddin University, English Studies major. Her Doctoral Degree was finished in Jakarta State University in Jakarta, 2012, Language Education department.

She was entrusted to a position in 2007 as a one of expert staff of Quality Assurance Board in her university for several years. In 2018, she occupied as expert staff of rector, Alauddin Islamic State University of Makassar. Currently she is also a teacher and examiner as well in Postgraduate Program in her campus. Several written works, books, and international published articles have been composed by the writer such as: Sexism in Language (Sociolinguistics studies, 2011), Correct Your Own Errors (2013), Communication Strategies (a case study, 2012), The Effects of Cooperative Learning Techniques and Sociological Learning Styles on Academic Writing Activity (article, 2018) 
Dr. Mardiana Nurdin is a member of Asia TEFL, Indonesian English Teachers Association (TEFLIN), and Auckland Applied Linguistics Research Network.

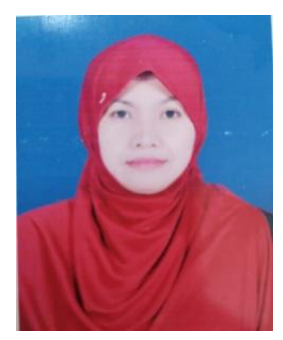

Djuwairiah Ahmad, a Professor in English Education, was born in Makassar, June 19 ${ }^{\text {th }}, 1970$. She completed her undergraduate study in the English Education Department of IKIP Ujung Pandang, Indonesia, in 1992. She got her Master of Education majoring in English Education at State University of Makassar, Indonesia, in 2000. Then, she achieved her second master degree in TESOL at Victoria University, Melbourne-Australia in 2006. Lastly, she got her doctoral degree in Linguistics at the Faculty of Letters, Postgraduate Program of Hasanuddin University, Indonesia, in 2014.

Currently, she is the head of Language Center of Alauddin State Islamic University of Makassar, Indonesia. She was previously the head of English Education Department for two consecutive periods (years of 2008 to 2015) and the secretary of the same department from 2000 to 2004. A number of books, written works, and published articles that have been produced by the writer include: Translation (Book, 2013), Effect of Time Allotment on Test Scores for Academic Writing of Indonesian Learners of English (Journal of Multicultural Education, 2021), Exploring Student Achievement and Perceptions in an Online Flipped Grammar Course (Indonesian Journal of Applied Linguistics, 2021). Her previous research interests were in English teaching and curriculum, materials development, and language assessment.

Prof. Ahmad is a member of Indonesian English Teachers Association (TEFLIN), Asia TEFL, Indonesian Linguistic Society (MLI), and Association of America-Indonesia Scholarship Awardee Alumni (ALPHA-I).

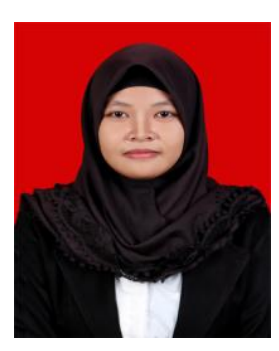

Al Amini Indah Sari born January $15^{\text {th }}, 1999$ in Maros, South Sulawesi Indonesia. She got her a bachelor degree in 2021 from Alauddin State Islamic University of Makassar (UIN Alauddin). She is currently pursuing her master's education specializing in English education at the Makassar State University, Indonesia.

She participated in several national and International conferences, including; Presenter at The 4th Annual Seminar on English Language Studies (ASELS) hosted by the Faculty of Cultural Sciences, Hasanuddin University of Makassar, in 2019; Presenter at The 2nd International Conference on English Language Education, held by English Education Department, Faculty of Tarbiyah and Teacher Training, UIN Alauddin Makassar, in 2020; and Presenter at The 5th Annual Seminar on English Language Studies (ASELS), held by English Language Studies Program, Faculty of Cultural Science, Hasanuddin University on December 13, 2020. 